\title{
Prevalence of common infections among employees in different work schedules.
}

Citation for published version (APA):

Mohren, D. C. L., Jansen, N. W. H., Kant, Y., Galama, J. M. D., van den Brandt, P. A., \& Swaen, G. M. H. (2002). Prevalence of common infections among employees in different work schedules. Journal of Occupational and Environmental Medicine, 44, 1003-1011. https://doi.org/10.1097/00043764-20021100000005

Document status and date:

Published: 01/01/2002

DOI:

10.1097/00043764-200211000-00005

Document Version:

Publisher's PDF, also known as Version of record

\section{Please check the document version of this publication:}

- A submitted manuscript is the version of the article upon submission and before peer-review. There can be important differences between the submitted version and the official published version of record.

People interested in the research are advised to contact the author for the final version of the publication, or visit the DOI to the publisher's website.

- The final author version and the galley proof are versions of the publication after peer review.

- The final published version features the final layout of the paper including the volume, issue and page numbers.

Link to publication

\footnotetext{
General rights rights.

- You may freely distribute the URL identifying the publication in the public portal. please follow below link for the End User Agreement:

www.umlib.nl/taverne-license

Take down policy

If you believe that this document breaches copyright please contact us at:

repository@maastrichtuniversity.nl

providing details and we will investigate your claim.
}

Copyright and moral rights for the publications made accessible in the public portal are retained by the authors and/or other copyright owners and it is a condition of accessing publications that users recognise and abide by the legal requirements associated with these

- Users may download and print one copy of any publication from the public portal for the purpose of private study or research.

- You may not further distribute the material or use it for any profit-making activity or commercial gain

If the publication is distributed under the terms of Article $25 \mathrm{fa}$ of the Dutch Copyright Act, indicated by the "Taverne" license above, 


\section{Prevalence of Common Infections Among Employees in Different Work Schedules}

\author{
Danielle C.L. Mohren, MSc \\ Nicole W.H. Jansen, MSc \\ IJmert Kant, PhD \\ Jochem M.D. Galama, PhD \\ Piet A. van den Brandt, PhD \\ Gerard M.H. Swaen, PhD
}

\section{Learning Objectives}

- Discuss possible mechanisms through which the work scheduleparticularly "shift work," which includes nighttime work-might influence the risk of contracting common infections.

- Compare the demographic and behavioral features of day workers and shift workers.

- Contrast the prevalence of common infections in day and shift workers, adjusting for type of work.

\section{Abstract}

This study examined the prevalence of common infections among employees in different work schedules. Self-administered questionnaire data from the Maastricht Cohort Study on "Fatigue at Work" $(n=12,140)$ were used. Job title was used as a matching variable between day and shift workers to control for their different work environment. We used a multilevel analysis of a two-level structure, in which the individual employees (level 1) were nested within job titles (level 2), adjusted for demographics, longstanding disease, health behavior, work-related factors, fatigue and sleep quality. Results from the multilevel analyses showed that, compared to day work, shift work was associated with a higher risk for common infections, with the highest risk in three-shift workers. Compared to day work, shift work was further associated with differences in health, health behavior, sleep, fatigue and perceived job characteristics, factors that may influence the occurrence of infections and should be taken into account in future studies as well. (J Occup Environ Med. 2002; 44:1003-1011)

From the Department of Epidemiology, Maastricht University, Maastricht, The Netherlands (Drs Mohren, Drs Jansen, Drs Kant, Dr van den Brandt, Dr Swaen) and Department of Medical Microbiology, University Medical Center St. Radboud, Nijmegen, The Netherlands (Dr Galama).

The Maastricht Cohort Study is part of the Netherlands concerted research action on "Fatigue at Work" granted by the Netherlands Organization for Scientific Research. This study was supported by grants from the Netherlands Organization for Scientific Research (NWO Grants No. 580-02.254 and No. 580-02.201). The authors would like to thank LGPM van Amelsvoort, PhD, for his valuable advice concerning the statistical analyses.

Address correspondence to: Danielle C.L. Mohren, Department of Epidemiology, Maastricht University, P.O. Box 616, 6200 MD Maastricht, The Netherlands; dcl.mohren@epid.unimaas.nl

The author has no commercial interest related to this article.

Copyright $\odot$ by American College of Occupational and Environmental Medicine

DOI: 10.1097/01.jom.0000034348.94005.74 ommon infections like common cold, flu-like illness, and gastroenteritis are endemic in the general population thereby causing considerable discomfort and absence from work. In a study by Feeney et $\mathrm{al}^{1}$ it was found that respiratory disorders and gastroenteritis accounted for 50 to $60 \%$ of all spells of absence. In recent years, evidence has accumulated that stress influences the susceptibility to and duration of infections. Several psychosocial factors have been linked to an increased risk for infections. Daily hassles and major life events have been connected to a higher risk for upper respiratory tract infections. ${ }^{2-6}$ Family functioning, measured with scales covering among others cohesion, adaptability and recent events within a family, ${ }^{7}$ has been associated with a higher risk for influenza-like illnesses. Also work-related stressors may play a role in the susceptibility to infections and several studies have demonstrated a link between the experience of work-related stressors and changes in immune activity. ${ }^{8-10}$ Psychological job demands, for example, have been described as a possible risk factor for the common cold. $^{11}$

Another work-related factor that is likely to be associated with common infections, constitutes shift work. Shift work can have a negative impact on the health and well-being of workers. ${ }^{12}$ Problems related to shift work fall into three main areas. ${ }^{13}$ First, biological disruption of physiological processes, including the sleep-wake cycle ${ }^{14,15}$ can result from shift work. Second, the impairment 
of physical health and psychological well-being ${ }^{16}$ and third the disruption of social and domestic life ${ }^{17,18}$ have been associated with shift work as well. Studies have shown that shift workers have an increased risk of cardio-vascular diseases, ${ }^{19-23}$ gastro-intestinal diseases, ${ }^{12,24,25}$ and diminished well-being. ${ }^{12}$

A few studies have reported depressed immune function in relation to shift work, which may explain an increased susceptibility to infections. ${ }^{26,27}$ Further, depression of immune function has been attributed to a disturbed circadian rhythm ${ }^{28}$ caused by periodic shifting of the light-dark, wake-sleep-cycles. ${ }^{26}$ Shift work may be a major cause of suboptimal sleep quality ${ }^{29}$ and has been related to a greater amount of insomnia, sleep deprivation, and daytime sleepiness. ${ }^{15}$ Cohen et $\mathrm{al}^{30}$ found that inefficient sleep is associated with an increased risk of colds. Moreover, we found that fatigue is associated with common infections. ${ }^{31}$ Fatigue can be regarded as a common complaint during infection, which afterwards can persist for months. On the other hand, it was found that fatigue can also precede a common infection.

The prevalence of infections may further be influenced by health behavior like smoking, drinking habits, and limited exercise. Increased smoking, drinking, ${ }^{32}$ and limited exercise $^{33}$ can influence the immune response. Both smoking and alcohol consumption are believed to suppress host resistance and thereby increase the risk of upper respiratory tract infections. ${ }^{34}$ Health behavior may also differ between day and shift workers and may possibly account for differences in infection rates. One of the most important physiological problems associated with shift work and the night shift in particular, is that working, eating, and sleeping phases are changed. ${ }^{25}$

Strong differences between day and shift workers have also been reported concerning other work conditions, such as, for example, deci- sion latitude and conflicts at work, ${ }^{35}$ as well as emotional, physical and psychological job demands. ${ }^{36,37}$ This emphasizes the need to control for differences in the work environment when examining work schedules. Approaches to take into account these confounders, are to include measures of perceived job characteristics in the analysis of shift work effects $^{38}$ and/or use job title as a matching variable in the analyses.

We are currently interested in the associations between work schedules and the prevalence of infections. The present study is part of the large scale Maastricht Cohort Study on "Fatigue at Work," in which workrelated and nonwork-related factors as well as the occurrence of common infections were measured on an individual level by means of selfadministered questionnaires. The aim of the present study was to investigate whether shift work is associated with a higher prevalence of common infections, such as common cold, flu-like illness, and gastroenteritis compared to day work, with day and shift workers matched on job title. We differentiated day workers from employees working three-shift, five-shift, or irregular-shift systems, while taking into account the role of demographics, health, health behavior, perceived job characteristics, sleep quality, and fatigue.

\section{Methods}

\section{Maastricht Cohort Study}

At baseline the Maastricht Cohort Study surveyed a large heterogeneous population of employees working in 45 different companies and organizations. ${ }^{39,40}$ Temporary employees, as well as employees with an employment of less than $50 \%$, were excluded. A total of 12,161 employees completed the baseline questionnaire. Written consent was obtained from all participants. The overall response was $45 \%$. Twenty-one questionnaires were discarded because of technical reasons,${ }^{41}$ resulting in a study popu- lation of 12,140 employees. Included were men and women, aged 18 to 65 years $(n=12,095)$.

The participants of the Maastricht Cohort Study received nine questionnaires at four-monthly intervals, with a total observation period of three years (1998-2001). The results of the present study are based on the first (baseline) questionnaire (May 1998). At baseline, exposures (workrelated factors, individual characteristics, domestic and social factors as well as information on job title) and outcomes were measured on an individual level using self-administered questionnaires.

\section{The Study Population}

For the present study we further excluded employees with multiple jobs $(n=497)$, since we have no information available on the content and work schedule of the other job. To study the effects of work schedules, employees involved in day work, three-shift, five-shift, or irregular-shift work were selected. All employees involved in other work schedules or those who did not provide information on their work schedule were excluded, resulting in a final study population of $8255 \mathrm{em}$ ployees.

The questions 'What is your job in the company/organization?' and 'What is your most important task?' were used to assess an employees' job title in the current job. The responses to these open-ended questions were used by trained coders to assign a job title, with a five-digit code, based on The Netherlands Standard Classification of Occupations $1992 .{ }^{42}$ From the employees, 88 did not indicate their function or most important task. These employees were excluded from further analyses. At baseline in 1998, the Maastricht Cohort Study captured 687 different job titles. Job title was used to match the employees in the different work schedule groups. For example, employees working three-shift systems were matched with a reference group of day workers with sim- 
ilar job titles. For each distinguished job title, there was a minimum of two employees in each work schedule. For the comparison of three-shift workers with day workers, 47 job titles were identified $(n=753$ for three-shift workers, $n=1114$ for day workers). Examples of job titles represented in both day work and threeshift systems were: production planner, operator, engine/bench fitter. For comparing five-shift workers and matched day workers, 58 job titles were identified $(n=947$ for five-shift workers, $n=1609$ for day workers). Examples of job titles represented in both day work and fiveshift systems were: machine operator, controller or tester electricmachinery, maintenance electrician. As regards irregular shift workers and matched day workers, 28 job titles were identified $(n=329$ for irregular shift workers, $n=573$ for day workers). Examples of job titles represented in both day work and irregular shift systems were mailman, enrolled nurse, care taker of the mentally handicapped or elderly.

\section{Work Schedules}

Regarding work schedules, employees were asked whether they were involved in irregular shifts, two-shift, three-shift, four-shift, or five-shift work, exclusively evening or night work, or whether they worked daytime only. In our study, the term shift work is used for a work schedule that includes night work. In the present study only day workers, three-shift, five-shift or irregular shift workers were included for investigating differences between the schedules. The direction of the shifts (clockwise, counterclockwise) varied between the companies. In the present study three-shift work involves three alternating teams, with a semi-continuous schedule, in which a weekly interruption of the production, mainly in the weekends, takes place. Five-shift work involves full continuous shift work, spread over 7 days including five alternating teams. Concerning working hours a week, five-shift work generally comprises 33 to 34 hours a week, whereas three-shift work comprises 38 to 40 hours a week. Employees working irregular shifts are involved in frequently deviating work hours, which can vary substantially every week. In the present study for irregular shifts we included only those employees reporting frequent night work within their shift.

\section{Infections}

The 4-month prevalence of infections was also determined using selfadministered questionnaires. Three common infections: common cold, flu-like illness, and gastroenteritis were inventoried as separate items in the questionnaires asking employees about the occurrence of common infections in the past four months. For clarification, a brief description of the infection was included in the question. This description mainly contained the typical symptoms of the infection. For common cold these symptoms were: clogged or running nose, a sore throat, coughing, and slight or no fever (temperature less than $38^{\circ} \mathrm{C}$ ), for flu-like illness: fever (temperature $38^{\circ} \mathrm{C}$ or more), with at least four of the following six complaints, muscular pain, fatigue, sore throat, clogged or running nose, coughing, headache. For gastroenteritis these symptoms included: slight or no fever, gastritis, nausea, vomiting, and/or diarrhea.

\section{Work Environment}

In this study we included measures regarding the experience of several demands at work. Decision latitude was assessed with the Dutch version of the Job Content Questionnaire using the scale Decision Latitude. ${ }^{43,44}$ The level of psychological job demands was measured with the Dutch version of the Psychological Job Demands scale of the Job Content Questionnaire. ${ }^{43,44}$ The level of emotional demanding work was measured using a five item scale consisting of two items of the Questionnaire Experience and Assessment of Work
(VBBA), ${ }^{45}$ two items of the Questionnaire on Work and Health $(\mathrm{VAG})^{46}$ and one self-formulated item. Physical demands were measured using a dichotomous item of the Dutch questionnaire on Work and Health (VAG) ${ }^{46}$

\section{Demographics and Health Variables}

Information on age, gender, the presence of a long-term disease, smoking, and drinking habits, was obtained through self-report in the baseline questionnaire. Information on the quality of sleep was obtained through one item asking employees "Did you sleep well in the past four months?." This item was scored on a four point scale (never, sometimes, usually, always). The Checklist Individual Strength (CIS) was used to measure prolonged fatigue. ${ }^{47}$ The CIS is a 20-item questionnaire developed to measure several aspects of prolonged fatigue. The CIS is a selfreport instrument consisting of four factors: subjective experience of fatigue, concentration, motivation, and physical activity level. Higher scores indicate a higher degree of fatigue, more concentration problems, reduced motivation or less activity. A composite CIS-total score, ranging from 20 to 140 , can be constructed by adding the individual's scores on the four factors. The Cronbach's alpha of the total scale is 0.93 . The cut-off point for case classification used in the present study was CIS total $>76$. This cut-off point was established in a separate pilot study by means of defined samples with differences in fatigue levels. ${ }^{48}$ All those employees scoring $>76$ were considered to be probable fatigue cases. $^{41}$

\section{Statistical Methods}

We calculated crude and adjusted odds ratios (ORs) and 95\% confidence intervals (CI) for associations between each of the three common infections (common cold, flu-like illness, and gastroenteritis) and each work schedule. The ORs were ad- 
TABLE 1

Descriptive Characteristics Study Population

\begin{tabular}{|c|c|c|c|c|c|}
\hline & & Day Work ${ }^{\dagger}$ & $\begin{array}{c}\text { Three-shift } \\
\text { Work }\end{array}$ & $\begin{array}{l}\text { Five-shift } \\
\text { Work }\end{array}$ & $\begin{array}{l}\text { Irregular } \\
\text { Shift Work }\end{array}$ \\
\hline & $\mathrm{N}$ (number of organizations) & $5,899(45)$ & $878(19)$ & $1,058(11)$ & $420(25)$ \\
\hline Demographics & Gender \% female & 32.6 & $11.6^{\star \star \star}$ & $6.1^{\star \star \star *}$ & $39.5^{\star *}$ \\
\hline \multirow[t]{8}{*}{ Health behavior } & Smoking \% & 22.5 & $46.7^{\star \star \star}$ & $35.3^{\star \star \star}$ & $37.1^{\star \star \star}$ \\
\hline & Alcohol use \% (glasses/wk) & & 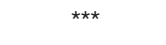 & * & 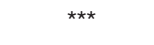 \\
\hline & - none & 24.4 & 37.1 & 28.8 & 34.3 \\
\hline & $-\geq 22$ & 2.8 & 3.3 & 3.3 & 2.6 \\
\hline & Exercise \% & & $* * \star$ & $\star \star$ & \\
\hline & - 0-1 times/wk & 30.5 & 44.1 & 36.3 & 32.6 \\
\hline & - 2-7 times/wk & 62.4 & 50.3 & 57.6 & 58.1 \\
\hline & $->7$ times $/$ wk & 7.1 & 5.5 & 6.1 & 9.3 \\
\hline Work-related factors & Physically demanding work \% & 11.8 & $51.6^{\star \star \star}$ & $34.8^{\star \star \star}$ & $71.9^{\star \star \star}$ \\
\hline \multirow{6}{*}{ Health } & Good sleep in past 4 months & & 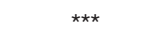 & $\star \star \star$ & ** \\
\hline & - never & 2.5 & 5.4 & 2.7 & 3.4 \\
\hline & - sometimes & 12.9 & 28.5 & 21.0 & 19.2 \\
\hline & - usually & 56.7 & 46.8 & 53.0 & 52.9 \\
\hline & - always & 27.9 & 19.2 & 23.3 & 24.5 \\
\hline & Fatigue $(\mathrm{CIS}>76) \%$ & 20.7 & $32.2^{\star \star \star}$ & $25.9^{\star \star \star}$ & 21.2 \\
\hline
\end{tabular}

Significant difference with day work: ${ }^{\star} P<0.05$, ${ }^{\star \star} P<0.01$, ${ }^{\star \star \star} P<0.001$.

${ }^{\dagger}$ Reference group for all three types of shift work.

‡ Scale range.

justed in several steps for demographics, longstanding disease, health behavior, psychological job demands (continuous variable), decision latitude (continuous variable), emotional demands (continuous variable), physical demands, and fatigue (continuous variable) and sleep quality. Each shift work type (three-shift, five-shift, and irregular-shift work) was compared with a reference group of day workers with respect to the prevalence of common infections. We used a multilevel analysis of a two-level structure, in which the individual employees (level 1) were nested within job titles (level 2). Additionally $t$ tests and Chi-square tests were used to test univariate differences between employees in the different shift work types versus day workers. All procedures were performed using SPSS for Windows release 9.0.0, SAS release 8.02, and GLIMMIX, a SAS Macro for the multilevel analyses.

\section{Results}

Table 1 shows descriptive characteristics of the study population before matching on job title. The percentage of women involved in threeand five-shift work was significantly lower compared to day work, whereas the percentage of women was significantly higher in irregular shift work compared to day work. Shift workers were on average younger of age compared to day workers. Smoking was significantly more prevalent in shift workers as compared to day workers, with the highest percentage of smokers $(46.7 \%)$ observed in three-shift workers. Differences in alcohol use were also found between day and shift workers. The highest percentage of employees who reported to exercise never or only once a week was found in three-shift workers. With regard to job characteristics substantial differences emerged be- tween day and shift workers. For example, the percentage of employees reporting their work to be physically demanding was substantially and significantly higher in all types of shift work compared to day work. Overall, the prevalence of employees reporting a long-term disease did not substantially differ between the work schedules, although the prevalence of a long-term disease was somewhat lower in five-shift work $(P<0.05)$ compared to day work. We found significant differences in sleep quality between employees in shift work and day work. Three-shift workers reported the highest percentage of poor sleep quality in the past 4 months. Compared to day work, the prevalence of fatigue was substantially higher in most shift work groups, with three-shift workers reporting the highest prevalence $(32.2 \%)$.

Table 2 shows the prevalence at baseline of common infections 
TABLE 2

Prevalence of Common Infections Among Different Work Schedules

\begin{tabular}{lcccc} 
& Day Work & Three-shift Work & Five-shift Work & Irregular Shift Work \\
\hline N (number of organizations) & $5,899(45)$ & $878(19)$ & $1,058(11)$ & $420(25)$ \\
Common cold \% & 53.0 & $57.5^{\star}$ & 51.0 & 55.5 \\
Flu-like illness \% & 22.4 & $31.2^{\star * \star}$ & 22.1 & $30.5^{\star * \star}$ \\
Gastroenteritis \% & 11.8 & $18.2^{\star \star *}$ & $15.4^{\star \star}$ & $15.1^{\star}$ \\
\hline
\end{tabular}

Significant difference with day work: ${ }^{\star} P<0.05,{ }^{* \star} P<0.01,{ }^{* \star \star} P<0.001$.

\section{TABLE 3}

Odds Ratios and 95\% Confidence Intervals for Common Infections by Shift Type Multilevel GLIMMIX Models

\begin{tabular}{|c|c|c|c|c|c|c|c|c|c|c|}
\hline & OR & $95 \% \mathrm{Cl}$ & OR $^{*}$ & $95 \% \mathrm{Cl}$ & $O^{\dagger}$ & $95 \% \mathrm{Cl}$ & $\mathrm{OR}^{ \pm}$ & $95 \% \mathrm{Cl}$ & $\mathrm{OR}^{\S}$ & $95 \% \mathrm{Cl}$ \\
\hline \multicolumn{11}{|l|}{ Common cold } \\
\hline 3-shift work & 1.42 & $1.14-1.76$ & 1.16 & $0.91-1.48$ & 1.14 & $0.88-1.46$ & 1.03 & $0.78-1.35$ & 1.03 & $0.78-1.36$ \\
\hline 5-shift work & 1.00 & $0.85-1.19$ & 0.83 & $0.69-0.99$ & 0.79 & $0.66-0.95$ & 0.77 & $0.63-0.95$ & 0.79 & $0.64-0.98$ \\
\hline Irregular shift work & 1.09 & $0.83-1.44$ & 1.02 & $0.76-1.37$ & 1.01 & $0.75-1.36$ & 0.92 & $0.66-1.27$ & 0.95 & $0.68-1.32$ \\
\hline \multicolumn{11}{|l|}{ Flu-like illness } \\
\hline 3-shift work & 1.72 & $1.34-2.20$ & 1.52 & $1.16-2.00$ & 1.41 & $1.07-1.87$ & 1.23 & $0.90-1.68$ & 1.23 & $0.90-1.70$ \\
\hline 5-shift work & 1.06 & $0.84-1.34$ & 0.92 & $0.72-1.17$ & 0.88 & $0.69-1.12$ & 0.82 & $0.64-1.06$ & 0.82 & $0.63-1.07$ \\
\hline Irregular shift work & 1.51 & $1.11-2.05$ & 1.40 & $1.01-1.95$ & 1.39 & $0.96-1.94$ & 1.52 & $1.06-2.18$ & 1.63 & $1.13-2.36$ \\
\hline \multicolumn{11}{|l|}{ Gastroenteritis } \\
\hline 3-shift work & 1.83 & $1.40-2.38$ & 1.25 & $0.92-1.70$ & 1.15 & $0.84-1.59$ & 1.05 & $0.73-1.51$ & 1.06 & $0.73-1.54$ \\
\hline 5-shift work & 1.64 & $1.29-2.08$ & 1.39 & $1.08-1.80$ & 1.34 & $1.03-1.74$ & 1.38 & $1.03-1.85$ & 1.42 & $1.05-1.91$ \\
\hline Irregular shift work & 1.40 & $0.95-2.06$ & 1.28 & $0.85-1.93$ & 1.22 & $0.80-1.86$ & 1.15 & $0.73-1.81$ & 1.17 & $0.73-1.88$ \\
\hline
\end{tabular}

For every shift type, the reference group consisted of employees in day work with comparable occupations.

* Corrected for age, gender, longstanding disease.

${ }^{\dagger}$ Additionally corrected for smoking, drinking habits and exercise.

${ }^{\ddagger}$ Additionally corrected for psychological job demands, decision latitude, physical demands, and emotional demands.

$\S$ Additionally corrected for sleep quality and fatigue.

among employees working in different work schedules. The occurrence of common cold is highest among three-shift workers $(57.5 \%)$ and irregular shift workers $(55.5 \%)$. Flulike illness is also most frequently reported by three-shift workers $(31.2 \%)$ and irregular shift workers $(30.5 \%)$. Finally, the highest prevalence for gastroenteritis was found among three-shift workers (18.2\%).

Because of the large differences observed between day and shift workers with regard to the perceived work-related demands, job title was used as a matching variable in multilevel analysis. Table 3 shows the ORs for the three distinguished common infections by shift type, using multilevel GLIMMIX models in which the individual employees were nested within job titles. Three-shift work was significantly associated with all three common infections (OR 1.42; CI 1.14-1.76 for common cold, OR 1.72; CI 1.34-2.20 for flu-like illness, OR 1.83; CI 1.402.38 for gastroenteritis). In general, for irregular shift workers similar but lower associations were observed. Five-shift work was only significantly associated with gastroenteritis (OR 1.64; 1.29-2.08). No significant differences were found for the prevalence of common cold and flu-like illness, when comparing five-shift workers with day workers. Adjusting for demographics and health factors (age, gender and long-term disease) and for health behavior (smoking, drinking habits, and exercise) resulted in weaker associations for all work schedules, except for the association between five-shift work and common cold. Compared to day work, five-shift work was then associated with a lower risk for common cold (OR 0.79; CI 0.66-0.95). Subsequently, the ORs for common infections were additionally adjusted for several work-related demands, which resulted in changes of the ORs for the association between work schedules and common infections as well. Most ORs decreased, whereas the OR regarding the association between irregular shift work and flulike illness increased (OR 1.52; CI 1.06-2.18). Also, the OR for the association between five-shift work and gastroenteritis increased (OR 1.38; CI 1.03-1.85). In the final analyses, the ORs were additionally adjusted for sleep quality and fatigue levels, which resulted in only slight changes of the ORs for all three common infections. Statistically significant ORs remained for the associations between five-shift work and common cold (OR 0.79 CI; 0.64 0.98 ); five-shift work and gastroenteritis (OR 1.42 CI 1.05-1.91), and irregular shift work and flu-like illness (OR 1.63; CI 1.13-2.36). 
Finally, to study the role of fatigue and sleep quality in the relationship between work schedules and common infections separately, we conducted an additional analysis, in which we adjusted the ORs only for demographics, the presence of a longstanding disease, fatigue and sleep quality. These analyses (specific data not shown) revealed that sleep quality and fatigue influenced the strength of the associations as well, although in general to a lesser extent as compared to the effect of perceived job demands.

\section{Discussion}

In this study we found that the prevalence of three common infections (common cold, flu-like illness, and gastroenteritis) differed significantly between employees involved in different work schedules. Threeshift workers reported the highest prevalence for all three infections. Taking into account the high prevalence of common infections and the fact that work schedules are not the primary 'etiological agent', the observed associations are quite large, moreover when considering the loss of productive work hours when infections result in employee absenteeism.

Because differences in workrelated factors are often large between day and shift workers, in this study job title was used as a matching variable. Employees with similar job titles in different work schedules were matched to account for differences in the work-environment. The crude ORs in the multilevel analyses revealed that shift work was clearly associated with a higher odds of common infections compared to day work. Three-shift work was strongly associated with all three infections. Compared to five-shift workers, three-shift workers have a working week comprising more hours. In addition, three-shift workers generally only have two (weekend) days available to recuperate before they switch to a new shift cycle. Others have observed that recovery from a shift did not occur by the end of the first rest day but might have occurred only by the end of the second rest day. ${ }^{49}$ The traditional weekly change of shifts, as for example seen in three-shift work, is often reported to be the worst solution. ${ }^{50,51}$

To elucidate possible underlying mechanisms relating work schedules to common infections, we adjusted in several steps consecutively for demographics, health, health behavior, job characteristics, sleep quality and fatigue. Adjustments for demographics, health status and health behavior resulted in lower odds for the association between work schedules and infections. This emphasizes the importance of correction for the above mentioned factors, since they are related both to infections and work schedules.

Subsequently, we corrected for several work-related demands. Although job title was used as a matching variable to take into account possible differences in demands, we still observed a change in the association between work schedules and infections after adjustment for workrelated demands. Though the day and shift workers were in comparable job titles, there were still differences with regard to the perceived demands of the individual worker. Compared to day workers, shift workers may perceive these job characteristics as more demanding possibly since they are fighting their sleep. Another possibility is that job demands in similar jobs actually are more demanding, when performed in shift work. We are aware that adjustment for job characteristics may constitute over control and thus could lead to underestimation of risks, because these job characteristics may be part of the causal pathway linking work schedules to common infections. Therefore, we assume that the relatively crude results, only adjusted for age, gender and long-term disease, are more likely to represent the actual effect of shift work on the prevalence of common infections. The analyses with adjustments for job characteristics, however, provided important additional information to disentangle possible mechanisms linking work schedules to common infections. This is in line with other studies showing an association between work-related stressors and immune function. ${ }^{9-11,52,53}$

Further, evidence supports the view that lack of sleep lowers resistance to infection and that during periods of sleep deprivation, respiratory tract infections occur more frequently. ${ }^{28}$ Shift work has been clearly related to disturbed sleep. ${ }^{15,54}$ First, their unusual work hours prevent shift workers from sleeping at the normal time. Second, when shift workers do have an opportunity to sleep, they have to do so in an environment that is geared toward the awakened state. Third, night work and day sleep affect the circadian rhythm. ${ }^{55}$ In a study by Härmä et al, ${ }^{15}$ for example, sleep complaints were more common in two- and three-shift workers as well as in irregular shift workers compared to day workers. In our study, shift work was also associated with poorer quality of sleep. In addition, shift workers had a significantly higher prevalence of fatigue. Higher fatigue levels are related to common infections as well. ${ }^{31}$ When controlling for sleep quality and fatigue levels, only minor changes appeared in the association between work schedules and common infections. A possible explanation for these small effects could be that perceived work demands next to sleep quality and fatigue, play a dominant role in the mechanism to explain the association between work schedules and common infections. Thus, because we corrected for perceived demands in our analysis before we corrected in the last step for sleep quality and fatigue, a large part of the association may already have been explained by the level of perceived work demands. Additional analyses in which we corrected for fatigue and sleep quality, but not for work demands, resulted in general in a decrease of the associa- 
tion between work schedules and common infections. These changes were smaller as compared to the effects of adjusting for work-related demands. Because perceived work demands are related to fatigue in other studies, ${ }^{56}$ we feel that sleep disturbances and fatigue could constitute another pathway linking work schedules to common infections. Because sleep deprivation may result in increased susceptibility, shift workers may experience more infections compared to day-workers. Altered light-dark cycles, which occur during shift work, are associated with disruptions of normal sleep patterns. ${ }^{57}$ Common perceptions that lack of sleep lowers resistance to infections and that infections develop during or after periods of sleep loss suggest that sleep deprivation is likely to impair immune function. ${ }^{58}$ Disorganization or disturbance of the sleepwake system interferes with the immunological, neuroendocrine, and thermal systems and contributes to pathological processes. Disruption of these systems is evident in diseases, such as infections. ${ }^{59}$

The data presented in the study have been collected in a large-scale cohort study among employees from 45 different companies. Despite the almost inevitable shortcoming of large cohort studies using questionnaires,${ }^{11}$ this study gave us the opportunity to study the relationship between common infections and different types of work schedules in a nonexperimental setting with participants observed in a natural environment with all the normal every day hassles. The items in the questionnaire concerning the common infections cover representative symptoms for common cold, flu-like illness and gastroenteritis. However, self-reports of gastroenteritis may also include reports of gastrointestinal disturbances in addition to actual infections, which are common complaints among shift workers. We are aware of the fact that self-reported illnesses may lead to under or over reporting. A study on the comparison between self-assessed and observer-assessed presence of colds, however, has demonstrated strong convergence between self-assessments of colds and physician ratings. ${ }^{60}$ With regard to work schedules, selection into shift work and outflow of less healthy shift workers moving from shift to daytime work might lead to an underestimation of the effects of shift work. ${ }^{19,23}$

Future studies could aim at the incidence of common infections among employees in different work schedules. Furthermore, it might be relevant to study effects of the direction of shift rotation in relation to the occurrence of infections, because it is argued that systems with a forward rotation may result in fewer problems for the shift worker than systems with a backward rotation. ${ }^{61} \mathrm{~A}$ forward rotating system is considered to be healthier because in the absence of external cues the sleepwake and other circadian rhythms run with a period of approximately 25 hours so sleep occurs later and later. ${ }^{61,62}$

In summary, the present study showed that shift work is associated with a higher prevalence of common cold, flu-like illness, and gastroenteritis compared to day work. Shift work was further associated with differences in health, health behavior, sleep, fatigue and perceived job characteristics, which constitute factors that should be taken into account in future studies examining the relationship between work schedules and health outcomes. More insight in these factors can be a starting point for interventions, when it is not feasible to change work schedules.

\section{References}

1. Feeney A, North F, Head J, Canner R, Marmot M. Socioeconomic and sex differentials in reason for sickness absence from the Whitehall II study. Occup Environ Med. 1998;55:91-98.

2. Graham NM, Douglas RM, Ryan P. Stress and acute respiratory infection. Am J Epidemiol. 1986;1243:389-401.

3. Cobb JM, Steptoe A. Psychosocial stress and susceptibility to upper respiratory tract illness in an adult population sample. Psychosom Med. 1996;58:404-412.

4. Cohen S, Tyrrell DA, Smith AP. Psychological stress and susceptibility to the common cold. N Engl J Med. 1991;325: 606-612.

5. Cohen S, Frank E, Doyle WJ, Skoner DP, Rabin BS, Gwaltney JM, Jr. Types of stressors that increase susceptibility to the common cold in healthy adults. Health Psychol. 1998;17:214-223.

6. Takkouche B, Regueira C, Gestal Otero JJ. A cohort study of stress and the common cold. Epidemiology. 2001;12:345-349.

7. Clover RD, Abell T, Becker LA, Crawford S, Ramsey CN, Jr. Family functioning and stress as predictors of influenza B infection. $J$ Fam Pract. 1989;28:535-539.

8. Vaernes RJ, Myhre G, Aas H, Homnes T, Hansen I, Tönder O. Relationships between stress, psychological factors, health, and immune levels among military aviators. Work Stress. 1991;5:5-16.

9. Endresen IM, Ellertsen B, Endresen C, Hjelmen AM, Matre, R, Ursin, H. Stress at work and psychological and immunological parameters in a group of Norwegian female bank employees. Work Stress. 1991;5:217-227.

10. Ursin H, Mykletun R, Tönder O, et al. Psychological stress-factors and concentrations of immunoglobulins and complement components in humans. Scand J Psychol. 1984;25:340-347.

11. Mohren DCL, Swaen GMH, Borm PJA, Bast A, Galama JMD. Psychological job demands as a risk factor for common cold in a Dutch working population. J Psychosom Res. 2001;50:21-27.

12. Costa G. The impact of shift and night work on health. Appl Ergon. 1996;27:9-16.

13. Smith L, Macdonald I, Folkard S, Tucker P. Industrial shift systems. Appl Ergon. 1998;29:273-280.

14. Åkerstedt T. Psychological and psychophysiological effects of shift work. Scand J Work Environ Health. 1990;16 Suppl 1:67-73.

15. Härmä M, Tenkanen L, Sjöblom T, Alikoski T, Heinsalmi P. Combined effects of shift work and life-style on the prevalence of insomnia, sleep deprivation and daytime sleepiness. Scand J Work Environ Health. 1998;24:300-307.

16. Bohle P, Tilley AJ. The impact of night work on psychological well-being. Ergonomics. 1989;32:1089-1099.

17. Monk TH, Folkard S. Making shift work tolerable. London/Washington: Taylor \& Francis; 1992.

18. Walker J Social problems of shiftwork. In: Folkard S, Monk TH, eds. Hours of work. Temporal factors in work-schedul- 
ing. New York: John Wiley \& Sons; 1985, p. 211-225.

19. Bøggild H, Knutsson A. Shift work, risk factors and cardiovascular disease. Scand J Work Environ Health. 1999;25:85-99.

20. Knutsson A, Åkerstedt T, Jonsson BG, Orth-Gomer K. Increased risk of ischaemic heart disease in shift workers. Lancet. 1986;8498:89-92.

21. Tenkanen L, Sjöblom T, Kalimo R, Alikoski T, Härmä M. Shift work, occupation and coronary heart disease over 6 years of follow-up in the Helsinki Heart Study. Scand J Work Environ Health. 1997;23:257-265.

22. Kristensen TS. Cardiovascular diseases and the work environment. A critical review of the epidemiologic literature on nonchemical factors. Scand J Work Environ Health. 1989;15:165-179.

23. Van Amelsvoort LPGM. Cardiovascular risk profile in shift workers. Cardiac control, biological and lifestyle risk factors. Wageningen: Wageningen University; 2000.

24. Gordon NP, Cleary PD, Parker CE, Czeisler CA. The prevalence and health impact of shiftwork. Am J Public Health. 1986;76:1225-1228.

25. Harrington JM. Shift work and health. A critical review of the literature on working hours. Ann Acad Med Singap. 1994; 23:699-705.

26. Curti R, Radice L, Cesana GC, Zanettini $\mathrm{R}$, Grieco A. Work stress and immune system: Lymphocyte reactions during rotating shift work. Preliminary results. Med Lav. 1982;73:564-569.

27. Kobayashi F, Furui H, Akamatsu Y, Watanabe T, Horibe H. Changes in psychophysiological functions during night shift in nurses. Influence of changing from a full-day to a half-day work shift before night duty. Int Arch Occup Environ Health. 1997;69:83-90.

28. Brown R, Pang G, Husband AJ, King MG. Suppression of immunity to influenza virus infection in the respiratory tract following sleep disturbance. Reg Immunol. 1989;2:321-325.

29. Regestein QR, Monk TH. Is the poor sleep of shift workers a disorder? Am J Psychiatry. 1991;148:1487-1493.

30. Cohen S, Doyle WJ, Skoner DP, Rabin BS, Gwaltney JM, Jr. Social ties and susceptibility to the common cold. JAMA. 1997;277:1940-1944.

31. Mohren DCL, Swaen GMH, Kant IJ, Borm PJA, Galama JMD. Associations between common infections and fatigue in a Dutch working population: results of the Maastricht Cohort Study on Fatigue at Work. Eur J Epidemiol. In press 2002.

32. Kiecolt Glaser JK, Glaser R. Method- ological issues in behavioral immunology research with humans. Brain Behav Immun. 1988;2:67-78.

33. Nieman DC. Exercise, upper respiratory tract infection, and the immune system. Med Sci Sports Exerc. 1994;26:128-139.

34. Cohen S, Tyrrell DA, Russell MA, Jarvis MJ, Smith AP. Smoking, alcohol consumption, and susceptibility to the common cold. Am J Public Health. 1993;83: 1277-1283.

35. Bøggild H, Burr H, Tüchsen F, Jeppesen HJ. Work environment of Danish shift and day workers. Scand J Work Environ Health. 2001;27:97-105.

36. Jansen NWH, Kant IJ, Nijhuis FJN, Van den Brandt PA. Work schedules as risk factors for need for recovery and fatigue: results from the Maastricht Cohort Study after one year follow-up. Shiftwork International Newsletter. 2001, 18:52.

37. Jansen NW, Kant IJ. Need for recovery related to working time arrangements: results from the Maastricht Cohort Study on fatigue at work. Int J Behav Med. 2000;7 Suppl 3:S9.

38. Parkes KR. Shiftwork, job type, and the work environment as joint predictors of health-related outcomes. J Occup Health Psychol. 1999;4:256-268.

39. Beurskens AJ, Bültmann U, Kant IJ, Vercoulen JH, Bleijenberg G, Swaen GM. Fatigue among working people: validity of a questionnaire measure. Occup Environ Med. 2000;57:353-357.

40. Kant IJ, Beurskens AJHM, Schröer CAP, et al. De Maastrichtse Cohort Studie naar langdurige psychische vermoeidheid in de arbeidssituatie [The Maastricht Cohort Study on fatigue at work]. TBV. 2000;8: 226-232.

41. Bültmann U, Kant IJ, Kasl S, Beurskens A, Van den Brandt P. Fatigue and psychological distress in the working population: psychometrics, prevalence, and correlates. J Psychosom Res. 2002;52: 445-452.

42. Central Bureau of Statistics. Standaard Beroepenclassificatie 1992 [The Netherlands Standard Classification of Occupations 1992]. 's-Gravenhage: SDU/uitgeverij; 1993.

43. Houtman I. Reliability and validity of the Dutch version of the Karasek Job Content Questionnaire. In: NIOSH/APA conference on Stress, Work, and Health. Washington DC: APA; 1995.

44. Karasek RA. The Job Content Questionnaire and User's Guide (version 1.1). Los Angeles: Department of Industrial and Systems Engineering, University of Southern California; 1985.

45. Van Veldhoven M, Meijman TF. Het meten van psychosociale arbeidsbelast- ing met een vragenlijst: de vragenlijst beleving en beoordeling van de arbeid (VBBA) [The measurement of psychosocial job demands with a questionnaire (VBBA)]. Amsterdam: NIA; 1994.

46. Gründemann RWM, Smulders PWG, De Winter CR. Handleiding Vragenlijst Arbeid en Gezondheid [Manual, Questionnaire on work and health]. Lisse: Swets \& Zeitlinger; 1993.

47. Vercoulen JH, Swanink CM, Fennis JF, Galama JM, Van der Meer JW, Bleijenberg G. Dimensional assessment of chronic fatigue syndrome. $J$ Psychosom Res. 1994;38:383-392.

48. Bültmann U, De Vries M, Beurskens AJHM, Bleijenberg G, Vercoulen JHMM, Kant IJ. Measurement of prolonged fatigue at work in the Maastricht Cohort Study: determination of a cutoff point. J Occup Health Psychol. 2000;5: 411-416.

49. Totterdell P, Spelten E, Smith L, Barton J, Folkard, S. Recovery from work shifts: How long does it take? J Appl Psychol. 1995;80:43-57.

50. Knauth P. The design of shift systems. Ergonomics. 1993;36:15-28.

51. Knauth P. Designing better shift systems. Appl Ergon. 1996;27:39-44.

52. Endresen IM, Vaernes R, Ursin H, Tönder O. Psychological stress-factors and concentration of immunoglobulins and complement components in Norwegian nurses. Work Stress. 1987;1:365376.

53. Kawakami N, Tanigawa $\mathrm{T}$, Araki $\mathrm{S}$, et al. Effects of job strain on helper-inducer $(\mathrm{CD} 4+\mathrm{CD} 29+)$ and suppressor-inducer $(\mathrm{CD} 4+\mathrm{CD} 45 \mathrm{RA}+) \mathrm{T}$ cells in Japanese blue-collar workers. Psychother Psychosom. 1997;66:192-198.

54. Åkerstedt T. Is there an optimal sleepwake pattern in shift work? Scand J Work Environ Health. 1998;24 Suppl 3:18-27.

55. Rutenfranz J, Colquhoun WP, Knauth P, Ghata JN. Biomedical and psychosocial aspects of shift work. A review. Scand J Work Environ Health. 1977;3:165-182.

56. Bültmann U, Kant IJ, Schröer CAP, Kasl $\mathrm{SV}$. The relationship between psychosocial work characteristics and fatigue and psychological distress. Int Arch Occup Environ Health. 2002;75:259-266.

57. Toth LA, Regh JE. Effects of sleep deprivation and other stressors on the immune and inflammatory responses of influenza-infected mice. Life Sci. 1998;63: 701-709.

58. Toth LA. Sleep, sleep deprivation and infectious disease: studies in animals. Adv Neuroimmunol. 1995;5:79-92. 
59. Moldofsky H. Sleep and the immune system. Int J Immunopharmac. 1995;17: 649-654.

60. Macintyre S, Pritchard C. Comparisons between the self-assessed and observer- assessed presence and severity of colds. Soc Sci Med. 1989;29:1243-1248.

61. Barton J, Folkard S. Advancing versus delaying shift systems. Ergonomics. 1993;36:59-64.
62. Van Amelsvoort LPGM, Schouten EG, Maan AC, Swenne KA, Kok FJ. 24-Hour heart rate variability in shift workers: Impact of shift schedule. J Occup Health. 2001;43:32-38. 